Kocaeli Journal of Science and Engineering

\title{
Six Sigma Methodology and an Application in the Textile Sector
}

\author{
Murat KARABULUT ${ }^{1, *}$ iD, PInar YILDIZ KUMRU² iD \\ ${ }^{1}$ Department of Industrial Engineering, Kocaeli University, Kocaeli, 41310, Turkey, Orcid Id: 0000-0002-1006-2024 \\ ${ }^{2}$ Department of Industrial Engineering, Kocaeli University, Kocaeli, 41310, Turkey, Orcid Id: 0000-0002-6729-7721
}

Article Info

\section{Research paper}

Received : August 15, 2018

Accepted : December 19, 2018

Keywords

Process Improvement

Quality Management

Sipoc Diagram

Six Sigma

\begin{abstract}
In today's world of increasing international trade, companies are suggested to learn, implement and maintain new production techniques in place of traditional production systems in order to sustain their assets. In this approach, we have worked on "Six Sigma", one of the strongest components of these socalled systems. Within the scope of this study, Six Sigma and its application areas are investigated, and as a result of the obtained findings, six sigma applications have been made in the textile industry where the quality is desired to be improved. In the study, conducted by following the six sigma's DMAIC (Define, Measure, Analyse, Improve, Control) steps, using the detection tools such as SIPOC (Suppliers, Inputs, Process, Outputs, Customers) diagrams, measurement systems analysis, root cause analysis, determination of poor quality sources and improvement on the basic problem have been made. The variation of the strips from the card and cer machines in the plant created great quality problems. Before the six sigma project, the average coefficient of variation value of the card machines was 2.02. With this project, the average coefficient of variation value of the card machines is aimed to be reduced to 0.5-1.5 range. After the six sigma project, the average voefficient of variation value of the card machines was reduced to 1.03 .
\end{abstract}

\section{Introduction}

Six Sigma anticipates to place customers at the center of production, to base all decisions on concrete data, to improve processes, to get success, and to achieve a systematic approach to the permanence of results. Since Six Sigma uses this methodology, it provides great benefits to the companies it employs and provides competitive advantages to these companies in the market.

Six Sigma is used by many companies in the world. According to Dave Cote, The Chief Executive Officer of Honeywell; there is more than one technical tool within powerful tools, an administrative and cultural exchange program. Using the DMAIC problem solving methodology consisting of Define, Measure, Analyze, Improvement and Control stages, Six Sigma is applied in many different areas today and very successful results are obtained. Six Sigma applications, as the basis for statistical thinking and statistical methodologies increase day by day [1].

Six sigma methodology is used in this project to improve the quality of production processes of a company

\footnotetext{
* Corresponding Author: karabulut.murat.44@gmail.com
}

operating in the textile sector and to meet customer demands. In the literature search section, information on Six Sigma strategy and methodology were given and explanations were made about the statistical techniques underlying the Six Sigma technique.

During the implementation phase of the workshop, application steps of Six Sigma (Define, Measure, Analyze, Improvement, Control) are followed and by the help of the solution development of Six Sigma technique is explained. The experimental results are analyzed by using the technical details used in the application. In the improvement phase, the solution approaches related to the problem are explained. The average Coefficient of Variation $(\mathrm{Cv})$ value was reduced from 2.02 to 1.03 after improvements.

\section{Literature Search}

\subsection{Six Sigma}

Six Sigma depends on analyzing and developing all the processes in each operation. Systems always have 
opportunities for improvement. The main thing is to recognize these opportunities and to create systems that will evaluate these opportunities. The Six Sigma approach is a widely used technique to minimize losses in the industry, reduce costs, increase productivity and provide customer satisfaction. Six Sigma, a scientific approach, that is systematic, based on continuous improvement, removes the variability which creates the source of the questions, adopts goals and management, requires full participation, develops long-lasting solutions and provides continuous improvement. Six Sigma, as understood from the explanations, is a statistical method that keeps customer satisfaction in the foreground, mostly reduces the error rates, increases the performance and productivity. In other words, the method focuses on maximum internal and external customer satisfaction and superior achievement.

Six sigma methodology can be applied in almost all sectors, from telecommunications to manufacturing, finance, healthcare and entertainment [2]. The companies that implement the Six Sigma method follow the efficiency of their processes with an index called sigma level. Sigma expresses the standard deviation, which is a measure of variability in statistics, how much the process or processes of the organizations in the business life are variable, how much error it makes, or how much of the losses are [3].

\subsection{The History of the Six Sigma Approach}

Looking at the beginning of the historical development of Six Sigma, Americans were actively expanding their markets in the 79s. In response to market expansion of the Japanese, the answer came from Motorola. Starting in 1979, Motorola reviewed the costs of poor quality due to scrap, reprocessing and inspection. In the decade of the 80 s, Motorola saw significant variability as an enemy, taking great steps in terms of quality and improvement with Six Sigma approach, achieving significant gains [4]. Bob Galvin, Chief Executive Officer of Motorola in 1987, made a plan; aiming to improve quality targets 10 times until 1989, 100 times improvement by 1991 and reaching Six Sigma sufficiency in 1992. Six Sigma competencies have been overcome by reaching an average of 5.4 sigma sufficiency in 1992 or 40 PPM and even going beyond it in some products and processes [5]. In the period of 1987-1992, manufacturing errors were reduced by 150 times with Six Sigma method and Motorola saved 2.2 billion dollars. Later, in the period of 1987-1996, it was announced by the authorities that the company saved $\$ 11$ billion [4]. Six sigma method aims to reach perfection by acquiring only 3.4 percent failure in a million production. In the Six Sigma studies, it is assumed that the process will deviate from $1.5 \sigma$ in the long term.
This means that the average of the process is allowed to deviate from the average of $1.5 \sigma$ to the left or right.

\subsection{Six Sigma Organization}

The success of Six Sigma depends on the well defined roles for everyone. For this reason, all the staff members of the Six Sigma organization are retitled and their job definitions are redefined [6].

\subsubsection{High Quality Council}

Senior management does not waste time learning about Six Sigma, if the most qualified personnel are not assigned for this job and if they do not provide the needed resources, projects will not have a chance to succeed. For this, it is essential to establish a top quality council, especially in large enterprises.

\subsubsection{Champion}

The Six Sigma champion is the person or people who observe the improvement projects on behalf of the top quality council. Among his main tasks are; to ensure that the remediation projects are consistent with the business objectives, to ensure coordination between the remediation teams and to set the overall goals of the projects [6].

\subsubsection{Process Owner / Project Owner}

In a company decided to make improvements by employing the Six Sigma, one of the senior executives is identified as Project owner. Tasks of the project owner; to assist the top management in selecting and evaluating the project, helping to identify the team members to be assigned important duties, preparing and implementing training plans [7].

\subsubsection{Expert Black Belt}

Expert Back Belt is a person who has the highest level of technical knowledge about the Six Sigma. Among the main tasks of the Expert Black Belt are to provide technical support to the improvement teams, in particular the selection and use of statistical methods, to assist the six sigma champions in determining the completion times of the projects.

\subsubsection{Black Belt / Green Belt}

They are the leaders of the improvement team. It is primarily responsible for the selection, implementation and 
conclusion of the improvement projects. By effectively using Six Sigma tools, they must be competent to bring fast and lasting solutions to business problems.

\subsubsection{Team Members}

They are the people who take part in the Six Sigma projects and provide the necessary support for the execution of the projects. When they support projects, they continue their operational duties. They need to have knowledge about Six Sigma philosophy, Six Sigma tools, basic measurement and analysis methods.

\section{The Methodology of Six Sigma}

Many methods are used in scientific improvement studies. However, it is known that all methods are based on the PDCA (Plan, Do, Check, Act) cycle developed by W. Edward Deming. The PDCA cycle includes planning, doing, checking, and acting precautionary measures, respectively [8]. In the case of Six Sigma, the DMAIC (Define, Measure, Analyse, Improve, Control) cycle consisting of the initials of the processes is used to optimize the processes. The difference in the DMAIC cycle, which is basically similar to that of the PDCA, is that it also evaluates the measurement and recovery phases separately. The expansion of the Six Sigma stages is explained below:

\subsection{Identification Phase}

During the identification phase, the scope of the project is determined together with the customer's needs and requirements. First of all, a detailed description of the problem is made and it is aimed to establish the team which will provide the highest success in solution of the problem in accordance with the project plan and the current plan. After defining the problem, the critical points of the project are identified. In this stage, SIPOC (Supplier, Input, Process, Output, Customer), cause-effect diagrams are used to analyze the current situation.

\subsection{Measuring Phase}

It is aimed to measure the current process in such a way as to cover all aspects and then to redesign the process by analyzing the data obtained therefrom. Before the measurement run is performed, it must be ensured that the measurement process does not involve any manipulation. This step of studying is very important because the information from the process will determine the continuing ability and capacity to uncover the product or service. In the measurement phase, a random sample can be taken from the data, and a different hundred percent measurement method can be followed, such as measuring all parts [9].

\subsection{Analysis Phase}

The analysis phase is the phase in which the data obtained when the validated measurement system is analyzed by various statistical tools. At this stage, data is determined by normal distribution tests to see if they have normal distribution. The effect on the result of the inputs determined in the identification and measurement phases is analyzed with appropriate statistical tools. The reduction of input factors and the determination of the highest influences on the outcome are carried out during the analysis phase.

\subsection{Improvement Phase}

It is the stage of the improvement activities for the reasons determined by the statistical results collected during the analysis stage. In order to optimize the outputs, the information about which inputs need to be focused is taken from the previous phase of analysis and necessary improvements are made. This is the stage at which the problem will be solved and its effects are reduced.

\subsection{Control Phase}

The control phase, the last step of Six Sigma, is the phase in which the continuity of the effect of the changes made is the result of the healing phase. At this stage, processes are standardized and controlled to ensure that the remedies are permanent and sustainable.

\section{Six Sigma Application}

\subsection{Company Info}

Çalık Denim, the first company of Çalık Holding, is among the top 10 premium denim producers in the world today. The company, which designs original denim collections with innovative approaches developed in the strong R \& D center, serves the world's leading clothing companies such as $\mathrm{H} \& \mathrm{M}$, Zara, Topshop and River Island. The company has adopted Six Sigma philosophy in recent years and aims to benefit from Six Sigma tools in its production processes. Within this scope, Six Sigma projects have been initiated. In this application, it has been tried to develop a solution to the quality problem by taking the support of top management and operating it. The 
application is explained in detail below.

\subsection{Application}

\subsubsection{Identification Phase}

Project Title: Reduction Coefficient of Variation
$(\mathrm{Cv})$ on card, cer and roving machines.

Problem Definition: Variation of $\mathrm{Ne}$ (Yarn Thickness) in strips produced in card and cer machines.

Problem: Because of $\mathrm{Ne}$ variation, it is the production of strips in different numbers.

The strips produced in different numbers due to the variation of $\mathrm{Ne}$ are described in Figure 1.

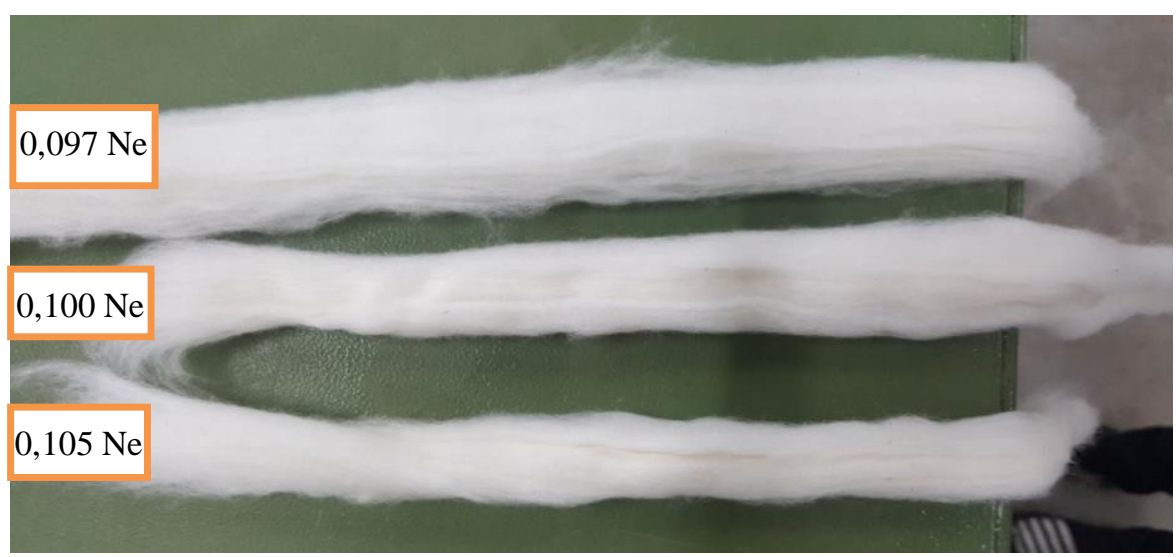

Figure 1. Strips produced in different numbers.

The $0.97 \mathrm{Ne}$ and $0.105 \mathrm{Ne}$ are undesirable thickness. The thickness required by the company should be 0.100 Ne.

Goal: The $\mathrm{Cv}$ values average of card machines is 2.02. Our goal is to reduce the average of $\mathrm{Cv}$ values to the standard operating range of 0.5-1.5.
The Sipoc diagram is the diagrams used to see an overview of the process that is considered to be improved in project work.

The Sipoc Diagram related to the process in which six sigma techniques are applied is given in Table 1.

Table 1. Sipoc diagram: cv difference map of cotton strip.

\begin{tabular}{|c|c|c|c|c|}
\hline Suppliers & Inputs & Process & Outputs & Customers \\
\hline $\begin{array}{c}\text { Blending } \\
\text { Department }\end{array}$ & Cotton & $\begin{array}{l}\text { Compressing the cotton with pressure on the DFK } \\
\text { machine (if the cotton DFK is not regularly compressed } \\
\text { or fed properly, it will cause number differences.) }\end{array}$ & $\begin{array}{l}\text { Homogeneous } \\
\text { mixed cotton }\end{array}$ & Card Machine \\
\hline $\begin{array}{c}\text { Physics } \\
\text { Department }\end{array}$ & Other Fibers & $\begin{array}{l}\text { The cotton is opened in the card machine to become } \\
\text { cheesecloth. }\end{array}$ & Cheesecloth & $\begin{array}{l}\text { 1.Passage Cer } \\
\text { Machine }\end{array}$ \\
\hline Card Department & Cheesecloth & $\begin{array}{l}\text { After the cotton has been converted into a card strip, } \\
\text { dubbing on the 1.passage cer machine (Thick and thin } \\
\text { strips may occur because the 1.passage cer machines } \\
\text { are not regulated. }\end{array}$ & Strip & $\begin{array}{l}\text { 2.Passage Cer } \\
\text { Machine }\end{array}$ \\
\hline Cer Department & Homogeneous strip & $\begin{array}{l}\text { Cotton is regulated on the cer machine after dubbing. ( } \mathrm{Cv} \\
\text { differences may occur due to regule problems.) }\end{array}$ & Regulated Strip & Roving Machine \\
\hline Roving Department & Regulated strip & $\begin{array}{l}\text { The strips coming out of the cer machine get twisted in } \\
\text { the roving machine and get the roving }\end{array}$ & Roving & Ring Machine \\
\hline Ring Department & Roving & $\begin{array}{l}\text { The rovings produced in the roving machine take the } \\
\text { yarn from the ring machine by taking shots and twisting. }\end{array}$ & Yarn & Bobbin Machine \\
\hline Bobbin Department & Yarn & $\begin{array}{l}\text { It is to wrap the irregularities of the yarns produced in } \\
\text { the ring machine to the bobbins. }\end{array}$ & Bobbin & Fixing Machine \\
\hline $\begin{array}{c}\text { Fixing } \\
\text { Department }\end{array}$ & Bobbin & $\begin{array}{c}\text { To give strength to the bobbins coming out of the } \\
\text { bobbin machine under suitable temperature and } \\
\text { humidity }\end{array}$ & $\begin{array}{l}\text { Ready to weave } \\
\text { rope }\end{array}$ & Weaving looms \\
\hline
\end{tabular}

After the Sipoc Diagram was prepared, brainstorming took place with 8 people on the team. Brainstorming result 19 points scored. The improvement in the first 8 items according to the points of the scoring is left to the rest because it will be based on the investment in the company and this will cost too much to operate. It is aimed to 
improve by changing the existing one without moving the company in accordance with the six sigma philosophy and without incurring extra expenses. The points to be improved are designated as keys.
The main reasons of the problem and other reasons affecting the main reasons were determined. All these reasons are shown in the fishbone diagram in Figure 2.

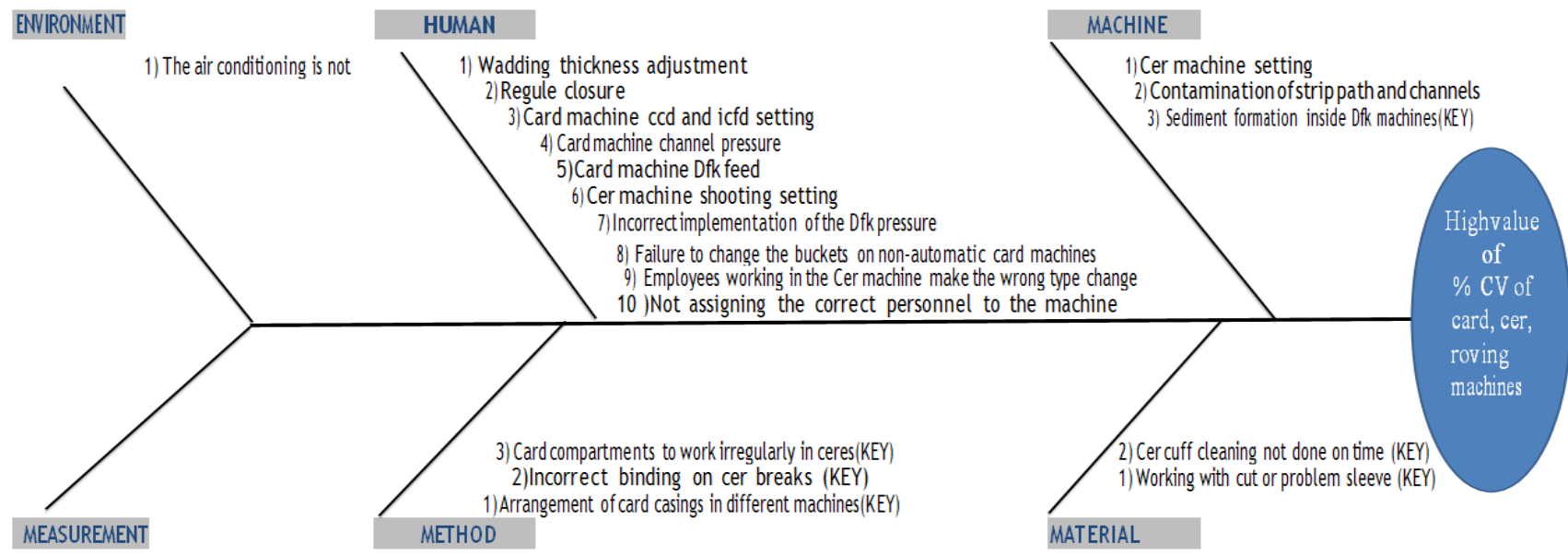

Figure 2. Fishbone diagram.

The problem is examined in detail and root-cause analysis is performed and the results are shown in Table 2.

Table 2. Root-cause analysis.

\begin{tabular}{|c|c|c|c|c|c|c|c|}
\hline & CAUSES & CAUSE 1 & CAUSE 2 & CAUSE 3 & CAUSE 4 & CAUSE 5 & ROOT CAUSE \\
\hline \multirow{7}{*}{ HUMAN } & $\begin{array}{l}\text { Cer machine } \\
\text { shots setting is } \\
\text { corrupted }\end{array}$ & $\begin{array}{l}\text { Excessive open } \\
\text { areas due to } \\
\text { mounting on the } \\
\text { plant }\end{array}$ & Incorrectly set & $\begin{array}{l}\text { Because the } \\
\text { settings are } \\
\text { made by the } \\
\text { masters }\end{array}$ & $\begin{array}{l}\text { Lack of } \\
\text { education }\end{array}$ & $\begin{array}{c}\text { Lack of } \\
\text { maintenance }\end{array}$ & Lack of education \\
\hline & $\begin{array}{l}\text { Closing of card } \\
\text { machine } \\
\text { regulated }\end{array}$ & $\begin{array}{l}\text { Excessive open } \\
\text { areas due to } \\
\text { mounting on the } \\
\text { plant }\end{array}$ & $\begin{array}{l}\text { Because the } \\
\text { machine can } \\
\text { not } \\
\text { compensate }\end{array}$ & $\begin{array}{l}\text { Because the } \\
\text { number does } \\
\text { not improve }\end{array}$ & $\begin{array}{c}\text { The machine } \\
\text { can not self- } \\
\text { regulate }\end{array}$ & $\begin{array}{l}\text { The feed is } \\
\text { irregular. }\end{array}$ & $\begin{array}{l}\text { The feed is } \\
\text { irregular. }\end{array}$ \\
\hline & $\begin{array}{l}\text { Card machine } \\
\text { wadding } \\
\text { thickness } \\
\text { adjustment } \\
\text { disorder }\end{array}$ & $\begin{array}{l}\text { Insufficient } \\
\text { supply }\end{array}$ & $\begin{array}{l}\text { Because the } \\
\text { feeding table } \\
\text { setting is not } \\
\text { made }\end{array}$ & $\begin{array}{c}\text { Lack of } \\
\text { maintenance }\end{array}$ & $\begin{array}{l}\text { Lack of } \\
\text { education }\end{array}$ & $\begin{array}{c}\text { Incorrectly } \\
\text { set }\end{array}$ & $\begin{array}{c}\text { Because the } \\
\text { feeding table } \\
\text { setting is not made }\end{array}$ \\
\hline & $\begin{array}{c}\text { Card machine } \\
\text { channel pressure } \\
\text { uncertainty }\end{array}$ & $\begin{array}{l}\text { Pressure settings } \\
\text { incorrectly } \\
\text { entered }\end{array}$ & $\begin{array}{c}\text { Because there } \\
\text { is no standard } \\
\text { work order }\end{array}$ & $\begin{array}{c}\text { Lack of } \\
\text { maintenance }\end{array}$ & $\begin{array}{l}\text { Lack of } \\
\text { education }\end{array}$ & $\begin{array}{c}\text { Incorrectly } \\
\text { set }\end{array}$ & $\begin{array}{c}\text { Because there is no } \\
\text { standard work } \\
\text { order }\end{array}$ \\
\hline & $\begin{array}{c}\text { Card machine } \\
\text { channel pressure } \\
\text { uncertainty }\end{array}$ & There are leaks & $\begin{array}{c}\text { Because the } \\
\text { wicks are worn } \\
\text { out }\end{array}$ & $\begin{array}{c}\text { Lack of } \\
\text { maintenance }\end{array}$ & $\begin{array}{l}\text { Lack of } \\
\text { education }\end{array}$ & $\begin{array}{c}\text { Incorrectly } \\
\text { set }\end{array}$ & $\begin{array}{c}\text { Because the wicks } \\
\text { are worn out }\end{array}$ \\
\hline & $\begin{array}{c}\text { Card machine } \\
\text { DFK feed roller } \\
\text { speed } \\
\text { misalignment }\end{array}$ & $\begin{array}{c}\text { Because it is } \\
\text { assembled from } \\
\text { different } \\
\text { factories }\end{array}$ & $\begin{array}{c}\text { Because some } \\
\text { the card } \\
\text { machine are } \\
\text { old }\end{array}$ & $\begin{array}{c}\text { Lack of } \\
\text { maintenance }\end{array}$ & $\begin{array}{l}\text { Lack of } \\
\text { education }\end{array}$ & $\begin{array}{c}\text { Incorrectly } \\
\text { set }\end{array}$ & $\begin{array}{c}\text { Because it is } \\
\text { assembled from } \\
\text { different factories }\end{array}$ \\
\hline & $\begin{array}{c}\text { Card machine } \\
\text { ccd and icfd } \\
\text { uncertainty }\end{array}$ & $\begin{array}{l}\text { Sensor settings } \\
\text { are corrupted }\end{array}$ & $\begin{array}{c}\text { Lack of } \\
\text { maintenance }\end{array}$ & $\begin{array}{c}\text { Lack of } \\
\text { maintenance } \\
\text { team }\end{array}$ & $\begin{array}{l}\text { Lack of } \\
\text { education }\end{array}$ & $\begin{array}{c}\text { Incorrectly } \\
\text { set }\end{array}$ & $\begin{array}{c}\text { Lack of } \\
\text { maintenance }\end{array}$ \\
\hline MACHINE & $\begin{array}{c}\text { The cer } \\
\text { machine's } \\
\text { regulator setting } \\
\text { is corrupted } \\
\end{array}$ & Not regulated & $\begin{array}{c}\text { Regule engine } \\
\text { setting is } \\
\text { incorrect }\end{array}$ & $\begin{array}{l}\text { Because the } \\
\text { machines are } \\
\text { old and coal } \\
\text { type }\end{array}$ & $\begin{array}{l}\text { Lack of } \\
\text { education }\end{array}$ & $\begin{array}{c}\text { Incorrectly } \\
\text { set }\end{array}$ & $\begin{array}{l}\text { Because the } \\
\text { machines are old } \\
\text { and coal type }\end{array}$ \\
\hline ENVIRONMENT & $\begin{array}{c}\text { The air } \\
\text { conditioning is } \\
\text { not stable }\end{array}$ & $\begin{array}{c}\text { Excessive open } \\
\text { areas due to } \\
\text { mounting on the } \\
\text { plant }\end{array}$ & $\begin{array}{c}\text { Because the air } \\
\text { conditioning is } \\
\text { old }\end{array}$ & $\begin{array}{c}\text { Lack of } \\
\text { maintenance }\end{array}$ & $\begin{array}{l}\text { Lack of } \\
\text { education }\end{array}$ & $\begin{array}{c}\text { Incorrectly } \\
\text { set }\end{array}$ & $\begin{array}{c}\text { Excessive open } \\
\text { areas due to } \\
\text { mounting on the } \\
\text { plant }\end{array}$ \\
\hline
\end{tabular}


The problem is examined in detail and the workflow of this process is shown in Figure 3.

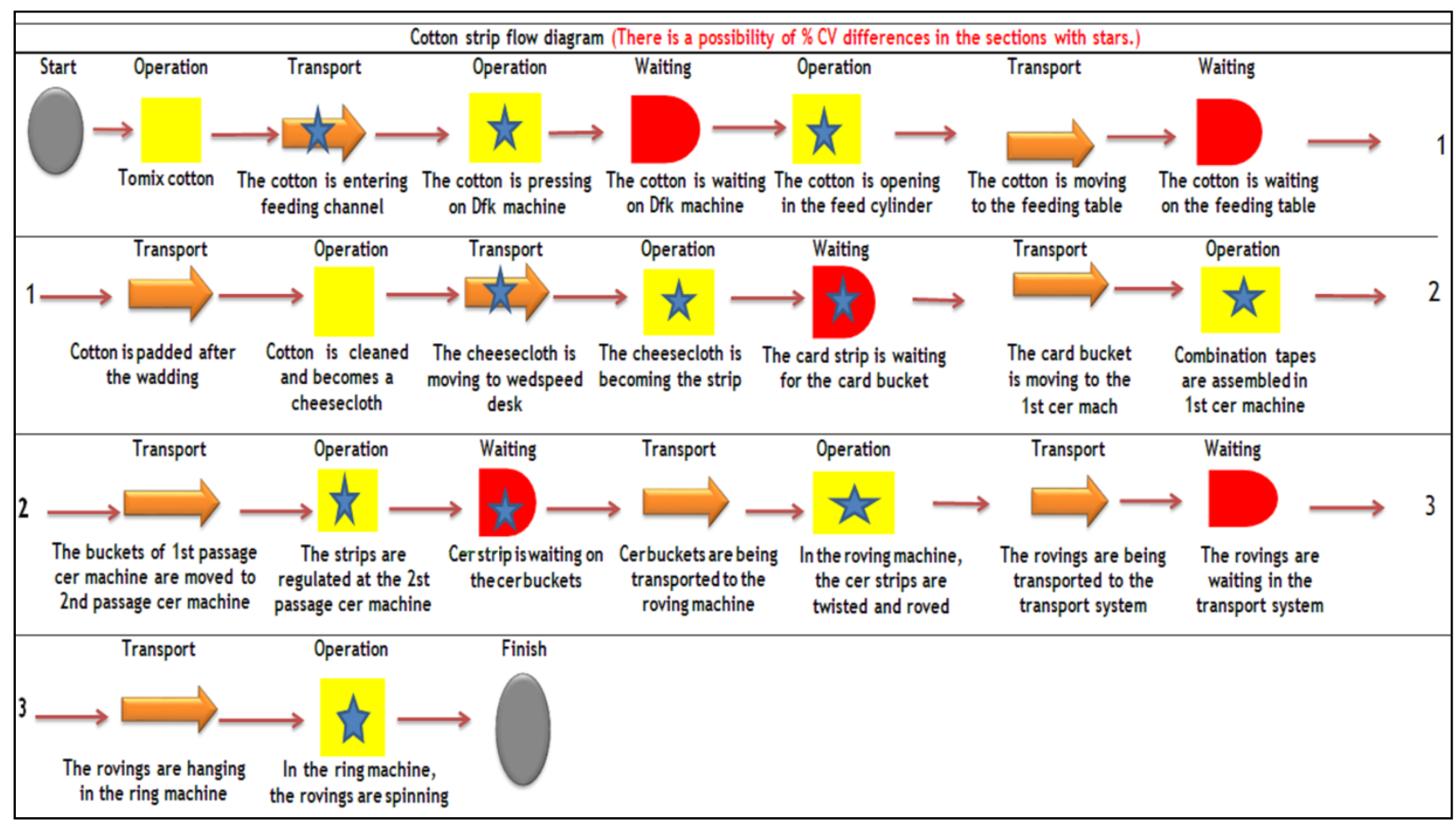

Figure 3. Cotton strip flow diagram.

The meanings of these signs are explained on the signs. These signs refer to operations, transporting and waiting operations. There is a high probability that $\mathrm{Cv}$ differences will occur in the sections with stars. The workflow of the process is explained with visual signs and the information about the stages of the process is transferred more easily.

\subsubsection{Measurement Phase}

The company has 72 cards in total. $\mathrm{Cv}$ values of 31 machines were examined within the scope of the project. Because the strips from these 31 machines were not of the desired quality. Strips were measured after the strips production was completed on each card. Based on these measurements, data was collected from machines that did not produce strips in the desired range. A total of 29 measurements were performed on 31 machines. The values obtained from the measurements are shown in Table A.1.

\subsubsection{Analysis Phase}

The measured values of each machine were entered into the minitab program and the standard deviation values were examined. When the machine $\mathrm{Cv}$ values were examined, 4 machines with the most variation were determined. The variations of these 4 machines and the average $\mathrm{Cv}$ values are shown in Figure 4.

\subsubsection{Improvement Phase}

The improvements made in the key points are explained below:

Improvements made within the scope of the project:

1. The Wadding Feeding Part pressure fixed to 300 and the balancing pressure was balanced at \pm 5 . Tires of the problem machines changed.

2. Cer gravitational cleaning procedure was made and improvement was achieved in practice by providing training on the correct fastening of detached roving strips.

3. Card machine measuring sensor for regulation adjustment in the feed cylinder setting 0.50; card machine measuring sensor for $\mathrm{Cv}$ waving in the output of the card machine has been set 2.75 and the settings were checked.

4. The card machine wadding feeding roller speed was measured and checked to be between the standard values of 5.1 and $5.3 \mathrm{rpm}$.

5. The wadding thickness adjustment was made between 55 and 70 and the feeding roller speed pressure was set to $600-800$ pascal.

6. Cer muffs were recreated, a cleaning procedure was introduced, all the muffs were recreated, and a regular system was set up. 


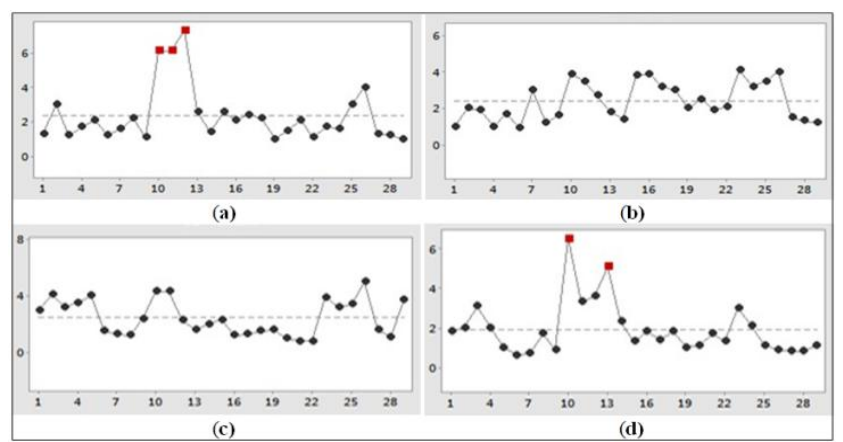

Figure 4. The average CV value of a-) the 25th machine was measured as $2.33 \mathrm{~b}-)$ the 26th machine was measured as $2.37 \mathrm{c}-$ ) the $32 \mathrm{nd}$ machine was measured as $2.45 \mathrm{~d}-$ ) the 46th machine was measured as 1.92 .

\subsubsection{Control Phase}

After the improvement phase, the data that we captured from 31 machines has been compared with the data that we had from the same 31 improvement machines. The results obtained from the improvements are explained in detail below.

The $\mathrm{Cv}$ values from 31 machines after improvements are shown in Table A.2.

The data of the 4 machines with the highest standard deviation value before and after the improvement is shown in the Figure 5-8.

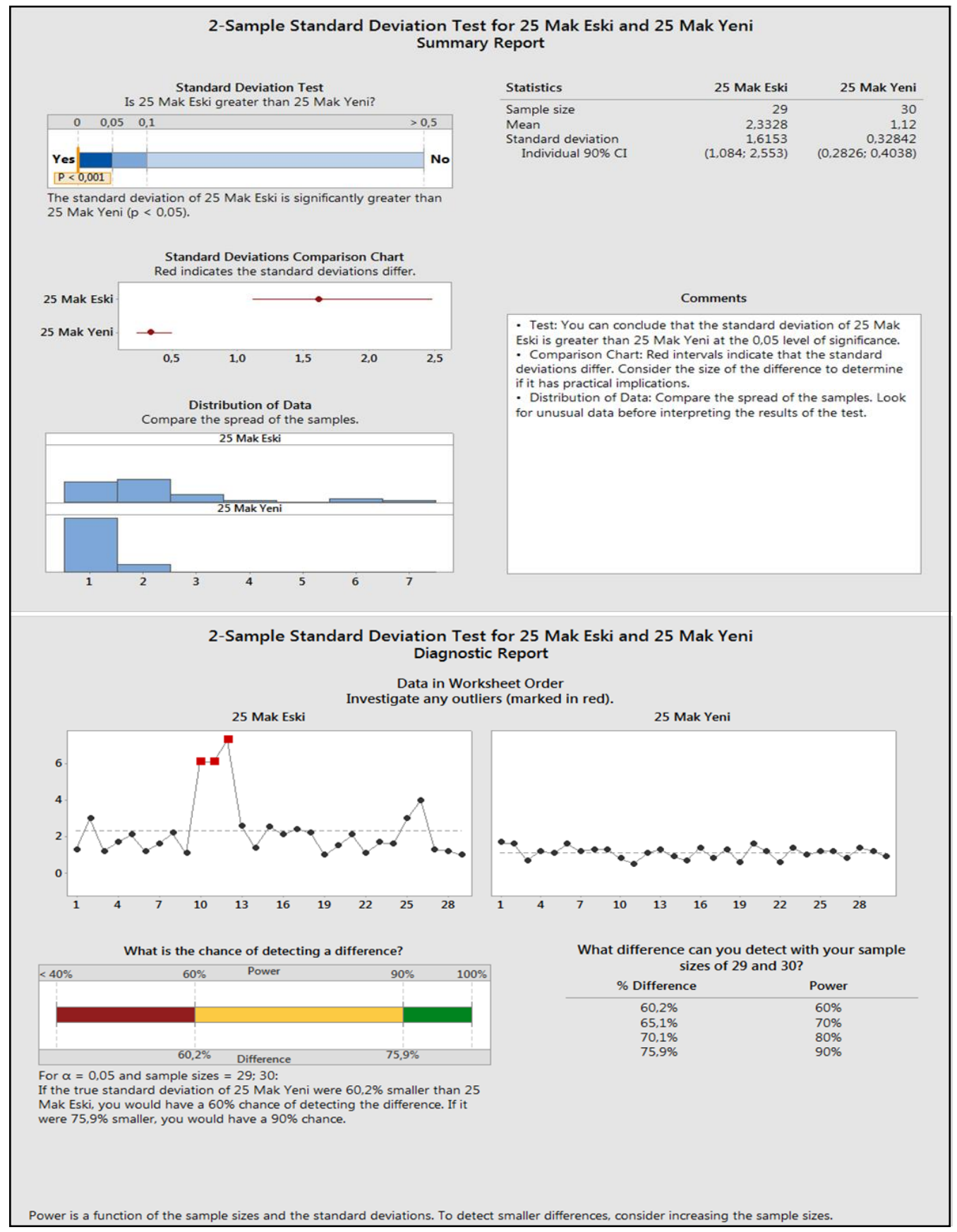

Figure 5. 25th machine's previous and next values. 
Since the 25th machine $\mathrm{P}$ value is less than 0.05 , we have achieved the statistical success. The average of the new $\mathrm{Cv}$ values of 25 th machine is smaller than before, and the improvement of the new $\mathrm{Cv}$ values is observed. The average of the new standard deviation of 25th machine is smaller than before at the 0.05 level of significance. Red intervals in comprasion chart indicate that the standard deviations differ. Consider the size of the difference to determine if it has practical implications. In the distribution of data, compare the spread of the samples. Look for unusual data before interpreting the result of the test. Diagnostic report indicates that if the true standard deviation of 25 th new value were $60.2 \%$ smaller than 25 th before. We would have $60 \%$ chance of detecting the difference. If it were 75.9 smaller, we would have a $90 \%$ chance.

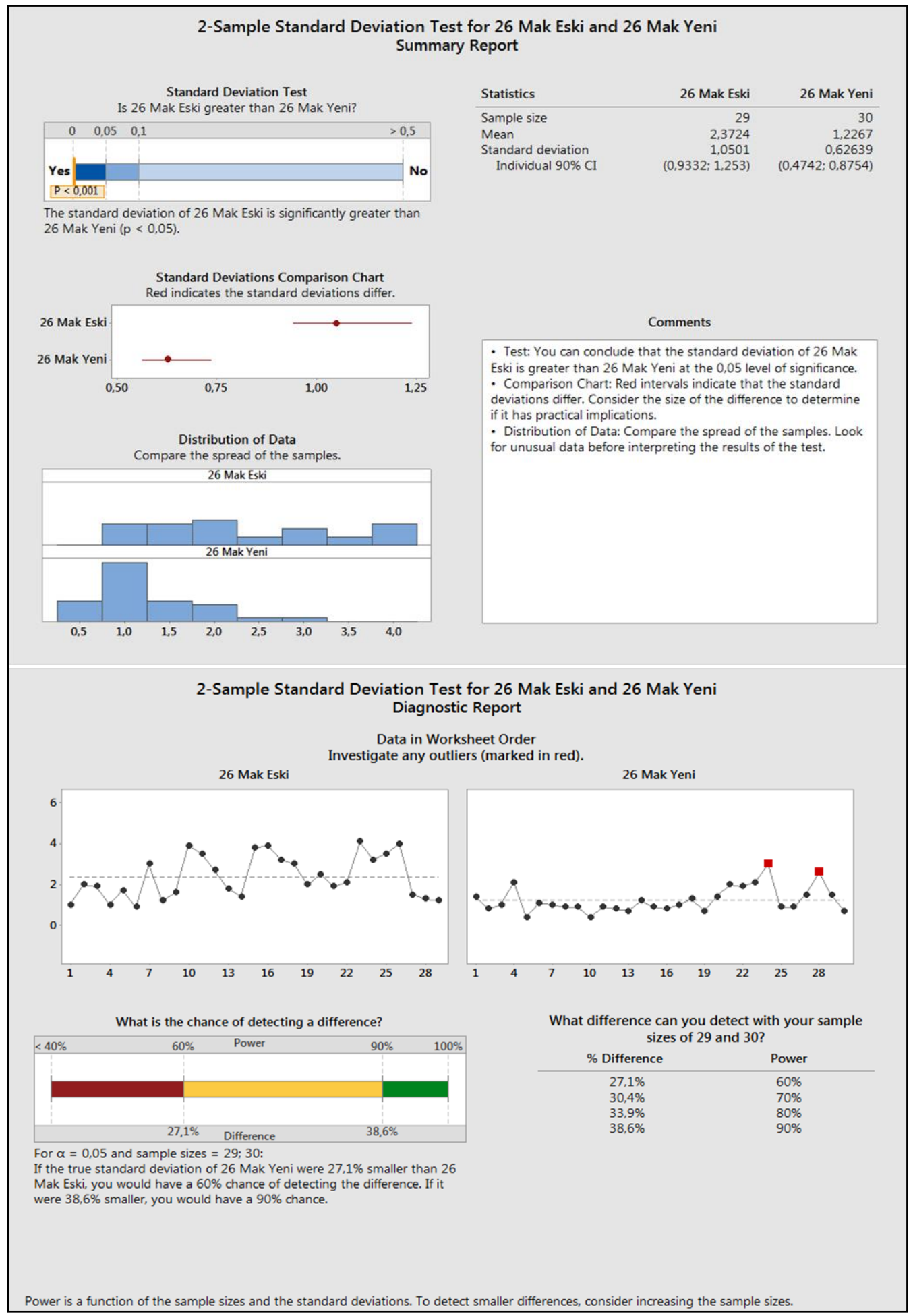

Figure 6. 26th machine's previous and next values. 
Since the 26th machine $\mathrm{P}$ value is less than 0.05 , we have achieved the statistical success. The average of the new $\mathrm{Cv}$ values of 26th machine is smaller than the previous, and the improvement of the new $\mathrm{Cv}$ values is observed. The average of the new standard deviation of 26th machine is smaller than the previous at the 0.05 level of significance. Red intervals in comprasion chart indicate that the standard deviations differ. Consider the size of the difference to determine if it has practical implications. In the distribution of data compare the spread of the samples. Look for unusual data before interpreting the result of the test. Diagnostic report indicates that if the true standard deviation of 26th new value were $27.1 \%$ smaller than 26th before. We would have $60 \%$ chance of detecting the difference. If it were 38.6 smaller, we would have a $90 \%$ chance.

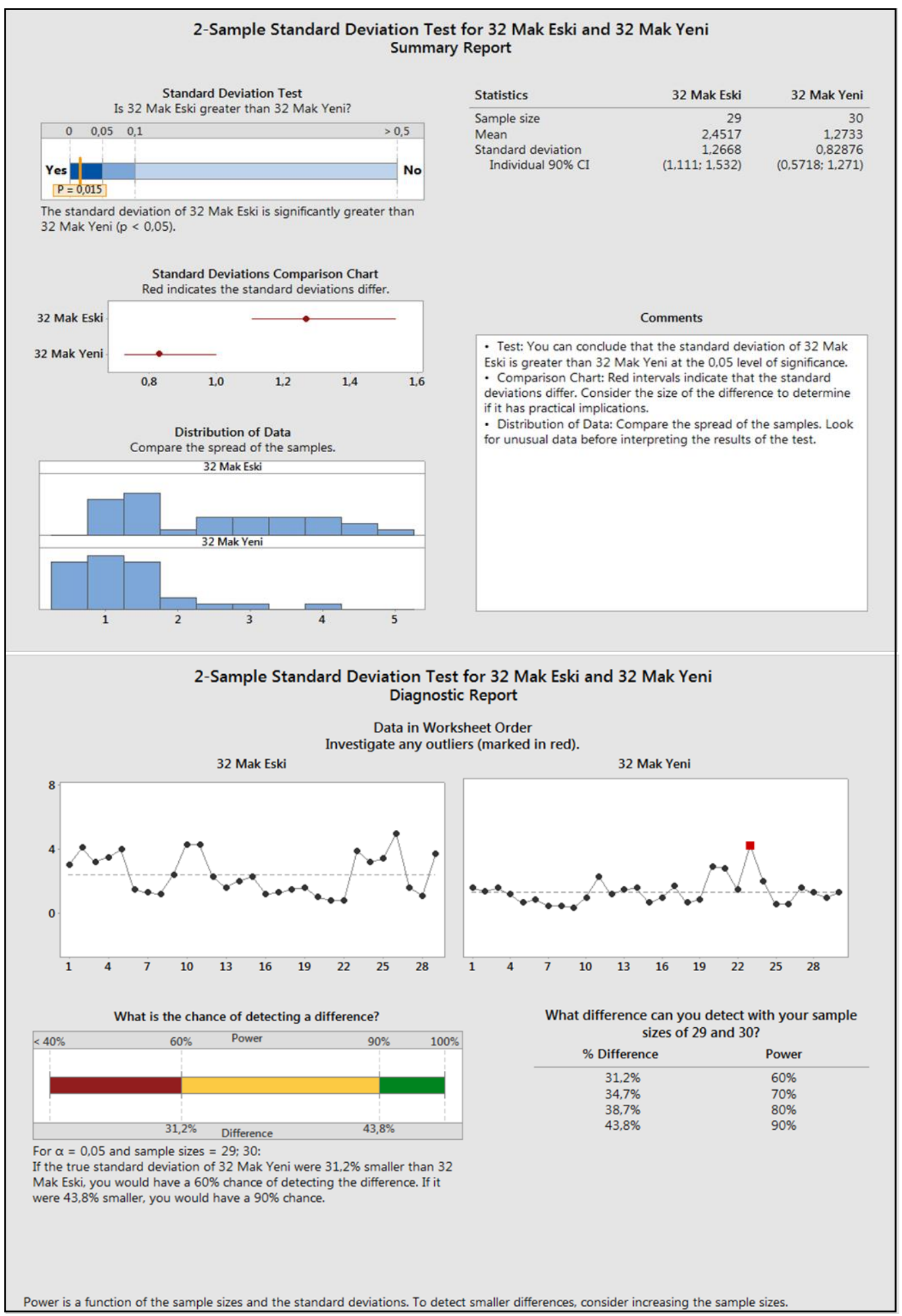

Figure 7. 32nd machine's previous and next values. 


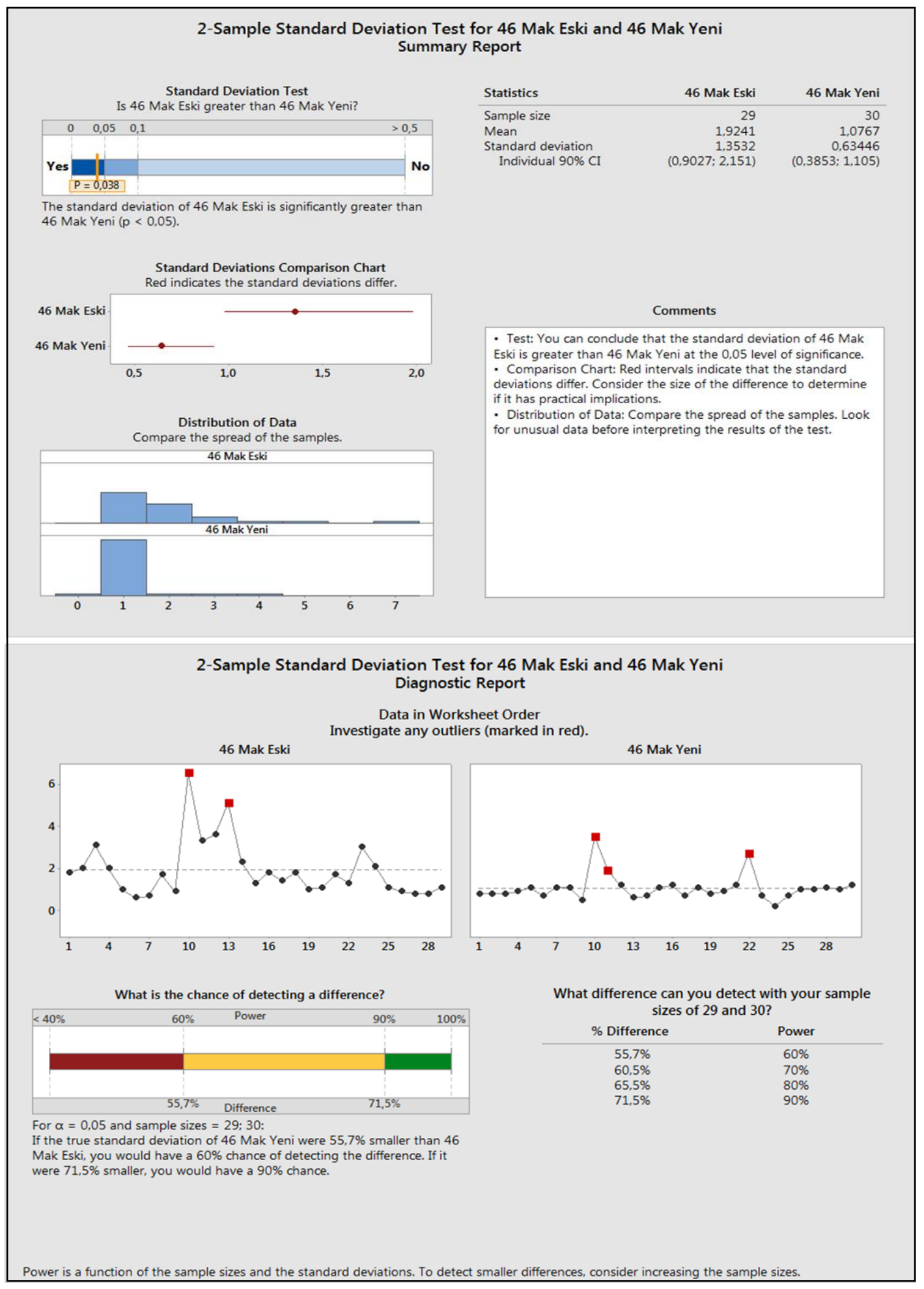

Figure 8. 46th machine's previous and next values.

Since the 32nd machine $P$ value is less than 0.05 , we have achieved the statistical success. The average of the new $\mathrm{Cv}$ values of 32nd machine is smaller than before, and the improvement of the new $\mathrm{Cv}$ values is observed. The average of the new standard deviation of 32nd machine is smaller than the previous at the 0.05 level of significance. Red intervals in comprasion chart indicate that the standard deviations differ. Consider the size of the difference to determine if it has practical implications. In the distribution of data compare the spread of the samples. Look for unusual data before interpreting the result of the test. Diagnostic report indicate that if the true standard deviation of 32 nd new value were $31.2 \%$ smaller than 32 nd before. We would have $60 \%$ chance of detecting the difference. If it were 43.8 smaller, we would have a $90 \%$ chance. 
Since the 46th machine $P$ value value is less than 0.05 , we have achieved the statistical success. The average of the new $\mathrm{Cv}$ values of 46th machine is smaller than before, and the improvement of the new $\mathrm{Cv}$ values is observed. The average of the new standard deviation of 46th machine is smaller than the previous at the 0.05 level of significance. Red intervals in comprasion chart indicate that the standard deviations differ. It may be considered the size of the difference to determine if it has practical implications. In the distribution of the data, you could compare the spread of the samples and look for unusual data before interpreting the result of the test. Diagnostic report indicates that if the true standard deviation of 46th new value were $55.7 \%$ smaller than 46th before. We would have $60 \%$ chance of detecting the difference. If it were 71.5 smaller, we would have a $90 \%$ chance.

\section{Results and Recommendations}

The CVs on card, cer and roving machines differed outside of the desired standard ranges, an ongoing problem in the production process of the operator and an important point to focus on. This problem was challenging as one of the major problems that led to production disruption and yield losses. In this study, the definition and the size of the problem are clearly presented and the targets are determined. The study has been done to collect concrete data related to the process, and the root causes of the problem have been identified from this data. The process has been taken as a whole from the first operation in the work flow, the operators and masters in the operation are included in the project and the problem is solved by creating synergy.

According to the famous statistician Fischer, the maximum acceptable level of a fault should have been at 0.05 . If the $P$ value in a test is less than 0.05 , it means that there is a significant difference in the comparison result. After the improvements in 4 machines with the highest standard deviation, $\mathrm{P}$ value of the data obtained from 4 machines was below 0.05 . These values indicate that we have achieved the statistical success. Before starting the six sigma project, the $\mathrm{CV}$ value of the card machine was 2.02. As a target in the scope of the project, it is aimed that the card machine $\mathrm{CV}$ value average will be drawn to the standard range of $0.5-1.5$. As a result of the improvements made, the average value of card machine $\mathrm{CV}$ value has been reduced to 1.03 and reached to the desired level. The improvement achieved after the project is described in Figure 9.

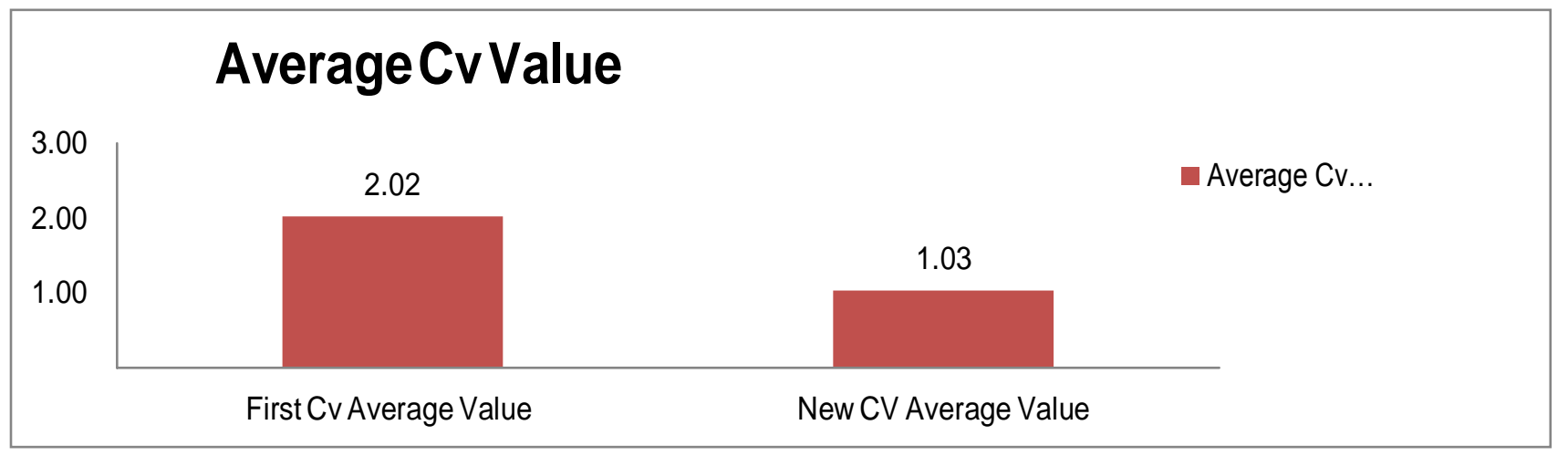

Figure 9. Previous and later average $\mathrm{Cv}$ values.

In this project, Six Sigma application in Çalık Denim company is shown with all steps. It is explained how to use the theoretical knowledge in the application phase, what to pay attention to in the application of each phase, how the data will be collected and evaluated in the Six Sigma process.

\section{Acknowledgements}

I also owe thanks to the members of the team who participated in the application project, Çalık Denim where the application project was made, and to the gratitude of continuous spiritual support throughout the process, mainly
Black Belt Bülent ADIGÜZEL due to the contribution of my work in the application part.

\section{References}

[1] Goh T.N, 2002. A Strategic Assessment Of Six Sigma. Quality And Reliability Engineering International, 18, pp. 403-410.

[2] Çeliknalça F.F, 2006. Evaluating Quality in MassHousing Projects Via Six Sigma: The Case of ODTÜKENT, Master's Thesis, Middle East Technical University, The Graduate School of Natural and Applied Sciences, Ankara. 
[3] Dağlıŏlu G., İnal T., Aksoy K., 2009. What is Six Sigma? Archive Source Browsing Journal, 18(2), p. 132 .

[4] Gürsakal N., 2008. Descriptive Statistics, 4th ed., Dora Publishing, Bursa.

[5] Eckes G., 2007. Six Sigma For Everyone (Translater: Adiyaman B.), MediaCat Publications, Istanbul, pp.10-11.

[6] Baş T., 2003. Six Sigma, 5th ed., Quality Office Publications, İstanbul.

[7] Işı̆̆ıçok E., 2005. Hypothesis Testing for Six Sigma Black Belts Roadmap, Sigma Center Management
Systems, Bursa.

[8] Özgen G., 2006. Six Sigma Methodology and an Application in the Electricity Sector, M.Sc. Thesis, Institute of Natural and Applied Sciences, Gazi University, Ankara.

[9] Dmaic, 2010. Brief Description of DMAIC Applications, p.15, https://www.isixsigma.com /new-to-six-sigma/dmaic/six-sigma-dmaic-roadmap. (Access Date: 23.12.2018).

\section{Appendices}

Table A.1 and Table A.2 are shown on pages 19-20. 
Table A.1. First Cv values (Machine no:1-15).

\begin{tabular}{|c|c|c|c|c|c|c|c|c|c|c|c|c|c|c|c|}
\hline \multicolumn{16}{|c|}{ First Cv Values } \\
\hline $\begin{array}{c}\text { Machine } \\
\text { No }\end{array}$ & 1 & 2 & 3 & 4 & 5 & 6 & 7 & 8 & 9 & 10 & 11 & 12 & 13 & 14 & 15 \\
\hline 25 & 1.3 & 3 & 1.2 & 1.7 & 2.1 & 1.2 & 1.6 & 2.2 & 1.1 & 6.1 & 6.1 & 7.3 & 2.6 & 1.4 & 2.6 \\
\hline 26 & 1 & 2 & 1.9 & 1 & 1.7 & 0.9 & 3 & 1.2 & 1.6 & 3.9 & 3.5 & 2.7 & 1.8 & 1.4 & 3.8 \\
\hline 27 & 1.2 & 2 & 2 & 2 & 1.3 & 1.4 & 1.9 & 1.1 & 1.3 & 1 & 2.6 & 2.1 & 0.7 & 1.1 & 0.3 \\
\hline 28 & 1.2 & 0.9 & 2 & 2.5 & 3 & 1.1 & 1.9 & 0.7 & 1.8 & 0.4 & 0.7 & 2.4 & 0.1 & 2.5 & 2.3 \\
\hline 29 & 2 & 1.3 & 2 & 2.6 & 4 & 0.6 & 0.6 & 2 & 1.3 & 5.6 & 5.6 & 1.6 & 5.4 & 1.2 & 1.8 \\
\hline 30 & 2 & 2.2 & 2.3 & 2.5 & 2 & 0.5 & 1 & 2.1 & 2.3 & 0.2 & 1.3 & 1.3 & 0.4 & 1.3 & 2 \\
\hline 31 & 1.5 & 1.7 & 1.6 & 3 & 4 & 1.3 & 1.2 & 1 & 2.1 & 0.6 & 1 & 1 & 0.6 & 0.8 & 1.9 \\
\hline 32 & 3 & 4.1 & 3.2 & 3.5 & 4 & 1.5 & 1.3 & 1.2 & 2.4 & 4.3 & 4.3 & 2.3 & 1.6 & 2 & 2.3 \\
\hline 33 & 4 & 2.6 & 3.2 & 3.5 & 3 & 2 & 1.9 & 1 & 2.3 & 2.9 & 2.9 & 2.9 & 1.8 & 1.4 & 1.8 \\
\hline 34 & 3.7 & 3.5 & 4.2 & 4.1 & 4 & 0.8 & 2.1 & 0.9 & 0.9 & 0.9 & 0.8 & 0.8 & 0.6 & 4.2 & 0.5 \\
\hline 35 & 3.1 & 3.8 & 3.7 & 3.1 & 3.5 & 0.6 & 1.6 & 1.3 & 1 & 1.2 & 1.2 & 1.2 & 6.6 & 2.7 & 1.4 \\
\hline 36 & 3 & 3 & 2 & 3.7 & 4 & 0.3 & 1.6 & 2 & 6.1 & 1.2 & 1.2 & 1.2 & 1.3 & 3.1 & 1.4 \\
\hline 37 & 5 & 4.6 & 4.2 & 4.1 & 4.6 & 1.2 & 1.1 & 1.6 & 0.8 & 3.5 & 5.3 & 5.3 & 1.6 & 1.2 & 1.9 \\
\hline 38 & 3.8 & 3.9 & 3.2 & 3.4 & 5 & 1.6 & 1.1 & 3.7 & 0 & 1 & 1 & 3.3 & 1.3 & 2.8 & 1.1 \\
\hline 39 & 3.8 & 3.6 & 3.6 & 3.1 & 3.7 & 0.5 & 2.1 & 1.6 & 4.4 & 3.9 & 0.5 & 0.9 & 2.2 & 1.9 & 1.6 \\
\hline 40 & 3.5 & 4.1 & 4.5 & 6 & 2 & 1 & 2.2 & 2.3 & 0 & 2.4 & 2.4 & 2.6 & 2.6 & 1.9 & 2.5 \\
\hline 41 & 1 & 3.2 & 1 & 0.6 & 3 & 1.4 & 0.9 & 1.4 & 2.3 & 2.5 & 2.5 & 2.6 & 2.4 & 1.9 & 8.2 \\
\hline 42 & 0.5 & 0.5 & 1.8 & 3 & 2 & 1.1 & 1.4 & 1.3 & 1.2 & 1 & 1.1 & 1.2 & 1.6 & 3 & 1.5 \\
\hline 43 & 1.7 & 1.7 & 1.3 & 3 & 2.1 & 1.1 & 0.9 & 0.8 & 0.8 & 1.1 & 0.9 & 1.6 & 1.6 & 2.5 & 1.6 \\
\hline 44 & 4 & 3.5 & 3 & 3.2 & 2.8 & 0.8 & 0.6 & 1.4 & 0.8 & 1.4 & 1.2 & 1.3 & 1.3 & 2.1 & 1 \\
\hline 45 & 1.8 & 1.1 & 2 & 3 & 3.2 & 1.2 & 1.5 & 1.3 & 0.7 & 0.9 & 2.4 & 2.4 & 0.7 & 3 & 0.7 \\
\hline 46 & 1.8 & 2 & 3.1 & 2 & 1 & 0.6 & 0.7 & 1.7 & 0.9 & 6.5 & 3.3 & 3.6 & 5.1 & 2.3 & 1.3 \\
\hline 47 & 0.8 & 1.1 & 1.5 & 1.1 & 1 & 0.6 & 0.6 & 0.5 & 0.9 & 1.5 & 1.5 & 1.5 & 1.2 & 1.5 & 1.2 \\
\hline 48 & 0.5 & 0.4 & 1 & 2 & 1.3 & 0.6 & 0.8 & 0.6 & 0.9 & 1.6 & 3.1 & 2.1 & 2 & 4 & 0.9 \\
\hline 49 & 0.9 & 0.7 & 1.3 & 1.2 & 1.5 & 0.9 & 0.9 & 0.9 & 1.1 & 1.4 & 6 & 2.2 & 3 & 2 & 1 \\
\hline 50 & 2.1 & 2.4 & 2.6 & 2.4 & 2 & 0.8 & 0.5 & 0.9 & 1.6 & 2 & 0.6 & 0.9 & 2 & 2.6 & 6.1 \\
\hline 51 & 1.5 & 1.6 & 2.2 & 3 & 2 & 0.6 & 0.9 & 0.6 & 0.5 & 2.3 & 3 & 1.4 & 2.1 & 1.8 & 0.8 \\
\hline 52 & 1.2 & 2 & 1.8 & 2.1 & 3 & 0.9 & 1.1 & 1.1 & 0.6 & 1.8 & 3 & 0.9 & 2.8 & 1.6 & 0 \\
\hline 53 & 0.5 & 0.2 & 0.5 & 0.7 & 1 & 0.8 & 3.2 & 1.4 & 0.5 & 3.1 & 3.2 & 0.6 & 1.6 & 1.3 & 4.4 \\
\hline 54 & 1.2 & 1.3 & 1.5 & 1.6 & 1 & 0.8 & 3 & 1.1 & 0.8 & 1.2 & 3 & 1.5 & 1.1 & 1.8 & 0 \\
\hline 55 & 1.1 & 1.5 & 1.3 & 1.4 & 1.2 & 0.5 & 2 & 0.6 & 1.3 & 2.8 & 2 & 0.7 & 1.1 & 1.6 & 2.3 \\
\hline
\end{tabular}

Table A.1. (Cont.) First Cv values (Machine no:16-29).

\begin{tabular}{|c|c|c|c|c|c|c|c|c|c|c|c|c|c|c|}
\hline \multicolumn{15}{|c|}{ First Cv Values } \\
\hline $\begin{array}{c}\text { Machine } \\
\text { No }\end{array}$ & 16 & 17 & 18 & 19 & 20 & 21 & 22 & 23 & 24 & 25 & 26 & 27 & 28 & 29 \\
\hline 25 & 2.1 & 2.4 & 2.2 & 1 & 1.5 & 2.1 & 1.1 & 1.7 & 1.6 & 3 & 4 & 1.3 & 1.2 & 1 \\
\hline 26 & 3.9 & 3.2 & 3 & 2 & 2.5 & 1.9 & 2.1 & 4.1 & 3.2 & 3.5 & 4 & 1.5 & 1.3 & 1.2 \\
\hline 27 & 2.3 & 2.5 & 2 & 2 & 1.8 & 0.9 & 2.3 & 2.6 & 3.2 & 3.5 & 3 & 2 & 1.9 & 1 \\
\hline 28 & 3.4 & 2 & 2.1 & 1.8 & 1.5 & 1.3 & 0.8 & 3.5 & 4.2 & 4.1 & 4 & 0.8 & 2.1 & 0.9 \\
\hline 29 & 1.3 & 1.2 & 2 & 1.8 & 1.6 & 0.6 & 0.6 & 3.8 & 3.7 & 3.1 & 3.5 & 0.6 & 1.6 & 1.3 \\
\hline 30 & 1.2 & 2 & 1.8 & 2.1 & 3 & 0.2 & 1.2 & 3 & 2 & 3.7 & 4 & 0.3 & 1.6 & 2 \\
\hline 31 & 0.5 & 0.2 & 0.5 & 0.7 & 1 & 1.3 & 0.9 & 4.6 & 4.2 & 4.1 & 4.6 & 1.2 & 1.1 & 1.6 \\
\hline 32 & 1.2 & 1.3 & 1.5 & 1.6 & 1 & 0.8 & 0.8 & 3.9 & 3.2 & 3.4 & 5 & 1.6 & 1.1 & 3.7 \\
\hline 33 & 1.1 & 1.5 & 1.3 & 1.4 & 1.2 & 0.2 & 1.6 & 3.6 & 3.6 & 3.1 & 3.7 & 0.5 & 2.1 & 1.6 \\
\hline 34 & 3.5 & 3.2 & 3.1 & 2 & 2 & 0.8 & 0.6 & 4.1 & 4.5 & 6 & 2 & 1 & 2.2 & 2.3 \\
\hline 35 & 3.5 & 3 & 2.1 & 2 & 1.8 & 1.6 & 1.7 & 3.2 & 1 & 0.6 & 3 & 1.4 & 0.9 & 1.4 \\
\hline 36 & 2.1 & 2.4 & 2.2 & 1 & 1.5 & 0.2 & 1.3 & 1.3 & 0.4 & 1.3 & 2 & 3.9 & 0.5 & 0.9 \\
\hline 37 & 3.9 & 3.2 & 3 & 2 & 2.5 & 0.6 & 1 & 1 & 0.6 & 0.8 & 1.9 & 2.4 & 2.4 & 2.6 \\
\hline 38 & 2.3 & 2.5 & 2 & 2 & 1.8 & 4.3 & 4.3 & 2.3 & 1.6 & 2 & 2.3 & 2.5 & 2.5 & 2.6 \\
\hline 39 & 3.4 & 2 & 2.1 & 1.8 & 1.5 & 2.9 & 2.9 & 2.9 & 1.8 & 1.4 & 1.8 & 1 & 1.1 & 1.2 \\
\hline 40 & 3.6 & 3.1 & 3.7 & 0.5 & 2.1 & 0.8 & 0.8 & 0.8 & 0.6 & 4.2 & 0.5 & 1.1 & 0.9 & 1.6 \\
\hline 41 & 4.5 & 6 & 2 & 1 & 2.2 & 1.2 & 1.2 & 1.2 & 6.6 & 2.7 & 1.4 & 1.4 & 1.2 & 1.3 \\
\hline 42 & 1 & 0.6 & 3 & 1.4 & 0.9 & 3.6 & 3.6 & 3.1 & 3.7 & 0.5 & 2.1 & 1.6 & 4.4 & 1.3 \\
\hline 43 & 0.4 & 1.3 & 2 & 3.9 & 0.5 & 4.1 & 4.5 & 6 & 2 & 1 & 2.2 & 2.3 & 0 & 1.2 \\
\hline 44 & 0.6 & 0.8 & 1.9 & 2.4 & 2.4 & 3.2 & 1 & 0.6 & 3 & 1.4 & 0.9 & 1.4 & 2.3 & 0.5 \\
\hline 45 & 1.6 & 2 & 2.3 & 2.5 & 2.5 & 0.5 & 1.8 & 3 & 2 & 1.1 & 1.4 & 1.3 & 1.2 & 1.2 \\
\hline 46 & 1.8 & 1.4 & 1.8 & 1 & 1.1 & 1.7 & 1.3 & 3 & 2.1 & 1.1 & 0.9 & 0.8 & 0.8 & 1.1 \\
\hline 47 & 0.6 & 4.2 & 0.5 & 1.1 & 0.9 & 3.5 & 3 & 3.2 & 2.8 & 0.8 & 0.6 & 1.4 & 0.8 & 3.5 \\
\hline 48 & 0.8 & 0.8 & 0.8 & 0.6 & 4.2 & 0.5 & 2 & 3 & 3.2 & 1.2 & 1.5 & 1.3 & 0.7 & 3.5 \\
\hline 49 & 1.2 & 1.2 & 1.2 & 6.6 & 2.7 & 1.4 & 3.1 & 2 & 1 & 0.6 & 0.7 & 1.7 & 0.9 & 2.1 \\
\hline 50 & 1.2 & 1.2 & 1.2 & 1.3 & 3.1 & 1.4 & 1.9 & 2.5 & 3.6 & 3.1 & 3.7 & 0.5 & 3.3 & 1.2 \\
\hline 51 & 3.5 & 5.3 & 5.3 & 1.6 & 1.2 & 1.9 & 1.9 & 8.2 & 4.5 & 6 & 2 & 1 & 0.9 & 2.8 \\
\hline 52 & 1 & 1 & 3.3 & 3.3 & 2.8 & 1.1 & 3 & 1.5 & 1 & 0.6 & 3 & 1.4 & 2.6 & 1.9 \\
\hline 53 & 3.9 & 0.5 & 0.9 & 2.2 & 1.9 & 1.6 & 2.5 & 1.6 & 0.4 & 1.3 & 2 & 3.9 & 2.6 & 1.9 \\
\hline 54 & 2.4 & 2.4 & 2.6 & 2.6 & 1.9 & 2.5 & 2.1 & 1 & 0.6 & 0.8 & 1.9 & 2.4 & 1.2 & 1.9 \\
\hline 55 & 2.5 & 2.5 & 2.6 & 2.4 & 1.9 & 8.2 & 3 & 0.7 & 1.6 & 2 & 2.3 & 2.5 & 1.6 & 3 \\
\hline
\end{tabular}


Table A.2. New Cv values (Machine no:2-16).

\begin{tabular}{|c|c|c|c|c|c|c|c|c|c|c|c|c|c|c|c|}
\hline \multicolumn{16}{|c|}{ New Cv Values } \\
\hline Machine No & 2 & 3 & 4 & 5 & 6 & 7 & 8 & 9 & 10 & 11 & 12 & 13 & 14 & 15 & 16 \\
\hline 25 & 1.6 & 0.7 & 1.2 & 1.1 & 1.6 & 1.2 & 1.3 & 1.3 & 0.8 & 0.5 & 1.1 & 1.3 & 0.9 & 0.7 & 1.4 \\
\hline 26 & 0.8 & 1 & 2.1 & 0.4 & 1.1 & 1 & 0.9 & 0.9 & 0.4 & 0.9 & 0.8 & 0.7 & 1.2 & 0.9 & 0.8 \\
\hline 27 & 0.9 & 1.3 & 0.3 & 0.6 & 1.2 & 0.3 & 0.4 & 0.7 & 1.5 & 1.3 & 1.2 & 1.1 & 0.4 & 0.6 & 1.2 \\
\hline 28 & 0.5 & 0.3 & 1.4 & 0.8 & 1.3 & 0.7 & 0.5 & 0.5 & 1 & 1.1 & 1.1 & 0.9 & 0.7 & 1.2 & 0.7 \\
\hline 29 & 0.6 & 0.9 & 0.9 & 0.2 & 0.9 & 0.7 & 1.2 & 1.1 & 0.9 & 1.1 & 1 & 0.9 & 0.9 & 1.4 & 1.1 \\
\hline 30 & 0.3 & 1.2 & 1.2 & 0.3 & 0.7 & 0.9 & 1.1 & 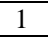 & 0.7 & 2.4 & 0.9 & 0.6 & 1.1 & 0.8 & 1 \\
\hline 31 & 1 & 1.4 & 0.6 & 0.5 & 0.6 & 0.8 & 1.4 & 1.9 & 0.6 & 1 & 0.8 & 1 & 0.8 & 1.5 & 0.7 \\
\hline 32 & 1.3 & 1.5 & 1.1 & 0.6 & 0.8 & 0.4 & 0.4 & 0.3 & 0.9 & 2.2 & 1.1 & 1.4 & 1.5 & 0.6 & 0.9 \\
\hline 33 & 1.1 & 0.8 & 1.3 & 0.6 & 0.9 & 0.6 & 0.2 & 0.1 & 0.2 & 1.8 & 1.2 & 1.2 & 1.2 & 0.8 & 0.6 \\
\hline 34 & 1.2 & 1.1 & 2.1 & 0.8 & 0.9 & 0.4 & 0.7 & 0.1 & 0.9 & 1.7 & 1.1 & 0.7 & 0.5 & 0.9 & 1.3 \\
\hline 35 & 1.3 & 0.7 & 1.8 & 0.4 & 0.7 & 0. & $\overline{0.6}$ & 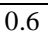 & 1.4 & 1.5 & 1.1 & 0.7 & 0.7 & 0.9 & 0.8 \\
\hline 36 & 0.8 & 1.3 & 0.6 & 0.6 & 0.9 & 0. & 0. & 0.7 & 1.1 & 2.6 & 0.9 & 0.9 & 0.9 & 1 & 0.6 \\
\hline 37 & 0.9 & 0.8 & 1.3 & 0.7 & 0.5 & 0.8 & 0.8 & 1.2 & 0.5 & 2.3 & 1 & 0.6 & 1.1 & 1.3 & 0.4 \\
\hline 38 & 0.7 & 1 & 2.1 & 0.3 & 0.6 & 0.7 & 0. & 1.2 & 1.3 & 2.2 & 0.7 & 0.8 & 1.3 & 0.7 & 0.8 \\
\hline 39 & 0.8 & 1.2 & 0.6 & 0.3 & 0.8 & 0.5 & 0.2 & 1.4 & 1.8 & 2.1 & 0.9 & 1.1 & 1 & 0.8 & 1 \\
\hline 40 & 0.4 & 0.9 & 1 & 0.5 & 0.3 & 0.3 & 1. & 0.8 & 1.7 & 1.4 & 0.9 & 1 & 0.6 & 0.8 & 1.2 \\
\hline 41 & 0.5 & 0.7 & 0.7 & 0.8 & 0.9 & 0.9 & 0 & & 1.8 & 1.7 & 0.8 & 0.7 & 0.8 & 0.8 & 0.6 \\
\hline$\overline{42}$ & 0.6 & 0.5 & 0.9 & 0.6 & 1.4 & 1.1 & 0. & 1.3 & 1.2 & 1.5 & 0.6 & 0.9 & 0.7 & 0.9 & 0.5 \\
\hline 43 & 0.8 & 0.7 & 0.8 & 0.9 & 0.9 & 1.2 & 0.9 & 4 & $\overline{0.9}$ & 0.9 & 1.1 & 0.5 & 1 & 1 & 0.9 \\
\hline 44 & 0.8 & 0.8 & 0.7 & 0.8 & 0.6 & 0.9 & 1.1 & 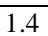 & 0.8 & 1.5 & 0.7 & 0.7 & 1.2 & 0.5 & 0.7 \\
\hline 45 & 0.7 & 0.8 & 0.7 & 0.8 & 1.5 & 1.1 & 0.9 & 1.7 & 0.6 & 0.9 & 1.1 & 0.9 & 0.9 & 0.7 & 0.8 \\
\hline 46 & 0.8 & 0.8 & 0.9 & 1.1 & 0.7 & 1.1 & 1.1 & 0. & 3.5 & 1.9 & 1.2 & 0.6 & 0.7 & 1.1 & 1.2 \\
\hline 47 & 0.9 & 0.8 & 0.8 & 0.8 & 0.6 & 0.9 & 0.9 & 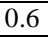 & 0.9 & 1.1 & 0.7 & 0.7 & 0.7 & 1.3 & 1.1 \\
\hline 48 & 0.8 & 0.5 & 0.7 & 0.8 & 0.8 & 0.5 & 0.9 & 0. & 0.8 & 0.7 & 1 & 0.9 & 1.1 & 0.9 & 0.9 \\
\hline 49 & 0.5 & 0.5 & 0.5 & 0.9 & 0.9 & 0.7 & 0.8 & 0.9 & 0.6 & 0.9 & 1.2 & 1 & 1 & 0.8 & 0.9 \\
\hline 50 & 0.8 & 0.8 & 0.9 & 0.6 & 0.5 & 0.9 & 1 & 0.6 & 0.5 & 0.7 & 1.1 & 0.6 & 0.9 & 0.9 & 0.5 \\
\hline 5 & 0.6 & 0.5 & 0.4 & 0.5 & 0.9 & 0.9 & 0.6 & 1.1 & 1. & 1.1 & 0.5 & 0.9 & 0.7 & 0.9 & 1 \\
\hline 52 & 0.5 & 0.9 & 1.3 & 0.8 & 0.8 & 1.2 & 1.1 & 0.6 & 1.2 & 0.9 & 0.7 & 1 & 0.8 & 0.7 & 1.6 \\
\hline 53 & 0.5 & 1.1 & 0.9 & 0.6 & 0.6 & 1.1 & 0.9 & 0.8 & 0.7 & 0.7 & 0.7 & 0.8 & 0.7 & 0.8 & 0.8 \\
\hline 54 & 0.6 & 0.5 & 0.4 & 0.9 & 0.9 & 0.6 & 1.1 & 0.9 & 1.2 & 0.9 & 0.6 & 0.5 & 1 & 0.9 & 1.2 \\
\hline 55 & 0.5 & 0.5 & 0.4 & 0.6 & 0.9 & 0.8 & 0.6 & 0.8 & 0.8 & 09 & 0.5 & 1.2 & 0.9 & 1.1 & 0.8 \\
\hline
\end{tabular}

Table A.2. (Cont.) New Cv values (Machine no:17-30).

\begin{tabular}{|c|c|c|c|c|c|c|c|c|c|c|c|c|c|c|}
\hline \multicolumn{15}{|c|}{ New Cv Values } \\
\hline Machine No & 17 & 18 & 19 & 20 & 21 & 22 & 23 & 24 & 25 & 26 & 27 & 28 & 29 & 30 \\
\hline 25 & 0.8 & 1.3 & 0.6 & 1.6 & 1.2 & 0.6 & 1.4 & 1 & 1.2 & 1.2 & 0.8 & 1.4 & 1.2 & 0.9 \\
\hline 26 & 1 & 1.3 & 0.7 & 1.4 & 2 & 1.9 & 2.1 & 3 & 0.9 & 0.9 & 1.5 & 2.6 & 1.5 & 0.7 \\
\hline 27 & 1.4 & 0.7 & 0.5 & 1.9 & 3.1 & 0.3 & 3.1 & 2.9 & 0.9 & 0.7 & 0.5 & 1.5 & 1.1 & 0.9 \\
\hline 28 & 1 & 1.2 & 0.7 & 1.7 & 3.4 & 1.4 & 2.1 & 1.8 & 1 & 1.1 & 0.5 & 1 & 0.1 & 1.2 \\
\hline 29 & 1.5 & 0.9 & 0.9 & 2.7 & 1.6 & 1.2 & 1.4 & 1 & 1.4 & 1.3 & 0.9 & 1.7 & 1.5 & 1.4 \\
\hline 30 & 1.3 & 0.6 & 0.9 & 3.1 & 2 & 5.8 & 2.1 & 1.2 & 0.6 & 0.8 & 1.2 & 3.4 & 1.2 & 1.1 \\
\hline 31 & 0.9 & 1.1 & 1 & 1.7 & 1.1 & 0.9 & 3.1 & 3.7 & 0.8 & 0.7 & 1.2 & 1.7 & 1.5 & 1.3 \\
\hline 32 & 1.6 & 0.6 & 0.8 & 2.8 & 2.7 & 1.4 & 4.1 & 1.9 & 0.5 & 0.5 & 1.5 & 1.2 & 0.9 & 1.2 \\
\hline 33 & 1.2 & 1.4 & 0.7 & 1.1 & 1.7 & 1.6 & 2.1 & 1.5 & 1.2 & 1.2 & 1.4 & 1.3 & 1.1 & 1 \\
\hline 34 & 0.9 & 0.8 & 0.9 & 1.9 & 2.1 & 1.5 & 3.1 & 2.7 & 1.1 & 1.4 & 1.1 & 1.4 & $\begin{array}{l}0.1 \\
\end{array}$ & 1.1 \\
\hline 35 & 0.5 & 1 & 1 & 2.5 & 1.8 & 2.7 & 1.1 & 1.9 & 0.6 & 0.6 & 1.2 & 3.7 & 1.7 & 1 \\
\hline 36 & 1.4 & 0.3 & 0.9 & 1.3 & 2.2 & 1.4 & 1 & 1.6 & 0.7 & 0.8 & 1.1 & 1.5 & 1.4 & 1.2 \\
\hline 37 & 1 & 0.6 & 1.1 & 1.2 & 3.2 & 1.4 & 1 & 2.1 & 0.7 & 0.8 & 0.9 & 1.1 & 0.1 & 1.1 \\
\hline 38 & 0.8 & 0.9 & 0.9 & 1 & 2.8 & 1.4 & 2.1 & 1.8 & 0.9 & 1 & 0.7 & 1.7 & $\begin{array}{l}1.7 \\
\end{array}$ & 4.6 \\
\hline 39 & 0.6 & 1.3 & 0.8 & 2.8 & 2.2 & 2 & 5.5 & 2.3 & 1.2 & 0.9 & 0.9 & 1.3 & 1.7 & 1.4 \\
\hline 40 & 0.3 & 1.1 & 1.2 & 1.3 & 3.2 & 2.8 & 0.9 & 1.1 & 1 & 0.7 & 1.1 & 1.7 & 1.8 & 1.4 \\
\hline 41 & 0.7 & 0.7 & 1 & 0.7 & 2.8 & 0.9 & 0.1 & 0.7 & 1 & 0.9 & 0.7 & 0.6 & 0.8 & 0.6 \\
\hline 42 & 0.9 & 0.9 & 1 & 1 & 1.9 & 0.9 & 0.2 & 1.1 & 0.8 & 0.7 & 0.5 & 0.5 & 0.8 & 0.5 \\
\hline 43 & 1.2 & 0.9 & 1 & 1.1 & 1.5 & 0.6 & 1 & 0.1 & 0.5 & 0.9 & 1 & 0.9 & 1 & 0.9 \\
\hline 44 & 1.1 & 0.7 & 0.9 & 1.3 & 0.9 & 1.3 & 1.3 & 2.1 & 0.9 & 0.6 & 0.7 & 0.6 & 0.8 & 0.6 \\
\hline 45 & 0.9 & 0.9 & 0.7 & 1.2 & 1 & 0.6 & 0.8 & 0.1 & 1.1 & 0.8 & 0.9 & 0.9 & 1.2 & 0.7 \\
\hline 46 & 0.7 & 1.1 & 0.8 & 0.9 & 1.2 & 2.7 & 0.7 & 0.2 & 0.7 & 1 & 1 & 1.1 & 1 & 1.2 \\
\hline 47 & 0.7 & 0.9 & 0.9 & 0.7 & 0.8 & 1.7 & 1.9 & 1.1 & 0.8 & 0.7 & 0.7 & 0.8 & 0.9 & 0.8 \\
\hline 48 & 0.6 & 0.6 & 1 & 0.2 & 0.1 & 0.5 & 0.1 & 1 & $\begin{array}{l}0.8 \\
\end{array}$ & 0.7 & 0.5 & 0.7 & 0.7 & 0.5 \\
\hline 49 & 0.6 & 0.8 & 0.9 & 1.8 & 1.2 & 0.7 & 1 & 1.2 & 1.1 & 1.2 & 1.1 & 1.4 & 0.9 & 0.7 \\
\hline 50 & 0.9 & 1 & 1 & 1.9 & 1.9 & 0.8 & 1.2 & 1.3 & 0.7 & 0.6 & 0.7 & 0.7 & 0.7 & 1.3 \\
\hline 51 & 0.9 & 0.6 & 0.7 & 1.2 & 0.7 & 1.5 & 1.3 & 0.9 & 0.9 & 0.9 & 0.5 & 0.5 & 0.4 & 0.4 \\
\hline 52 & 0.7 & 0.9 & 0.8 & 0.7 & 1.2 & 0.9 & 1 & 0.7 & 0.8 & 0.8 & 0.8 & 1.2 & 0.6 & 0.7 \\
\hline 53 & 0.9 & 0.8 & 0.7 & 1.6 & 1.3 & 1.1 & 1.4 & 1.1 & 0.9 & 0.7 & 0.9 & 0.8 & 0.9 & 0.9 \\
\hline 54 & 1.1 & 1.1 & 1.1 & 0.3 & 0.9 & 1.6 & 1.5 & 1.2 & 0.9 & 0.9 & 0.5 & 0.5 & 0.5 & 0.8 \\
\hline 55 & 0.9 & 0.7 & 1.2 & 1.3 & 0.1 & 0.9 & 1 & 0.2 & 1 & 0.7 & 0.5 & 0.5 & 0.6 & 0.5 \\
\hline
\end{tabular}

